\title{
SEPARATION OF CELL TYPES FROM EMBRYONIC CHICKEN AND RAT SPINAL CORD: CHARACTERIZATION OF MOTONEURON- ENRICHED FRACTIONS ${ }^{1}$
}

\author{
RONALD L. SCHNAAR ${ }^{2}$ AND ANNE E. SCHAFFNER \\ Laboratory of Biochemical Genetics, National Heart, Lung and Blood Institute, National Institutes of Health, Bethesda, Maryland 20205
}

\begin{abstract}
Single cell suspensions prepared from embryonic chick or rat spinal cords were separated into morphologically and functionally distinct subpopulations based on their buoyant densities. The lightest fraction (F-1) was highly enriched for cells containing the enzyme choline acetyltransferase (CAT), a marker for developing motoneurons. The morphology, biochemistry, and in vitro development of this and other spinal cord cell fractions isolated by the outlined procedure were investigated.

Spinal cords, dissected from 6-day chick or 12-day rat embryos, were dissociated with trypsin and applied to iso-osmotic metrizamide density gradients. After brief centrifugation, biochemical analysis revealed that cholinergic cells migrated to lower densities than other spinal cord cells. The use of discontinuous density gradients allowed rapid and simple isolation of three fractions of viable cells (designated F-1 to F-3, lowest to highest density).

Characterization of chicken and rat embryo cell fractions gave similar results. The cells in Fraction 1 were large with prominent nuclei and nucleoli, while those in F-2 and F-3 were distinctly smaller. Fraction 1 was highly enriched for cholinergic cells. The CAT specific activity (CAT/cell) was increased $400 \%$ in Fraction 1 compared to unfractionated cells, while CAT specific activity in F-2 and F-3 was reduced to $25 \%$ and less than $4 \%$ that of unfractionated cells, respectively. The recovery of cholinergic cells using this procedure was much better than with other published procedures; greater than half the spinal cord CAT activity was routinely recovered in the enriched fraction.

The cholinergic-enriched cells (F-1) were unique in their in vitro growth characteristics. All fractions had neuronal cells, while non-neuronal cells were distributed primarily in F-3, fewer in F-2, and were essentially absent from F-1. Neurons in F-2 and F-3 remained viable under a variety of conditions, most of which were not supportive of F-1 cell survival. The cholinergic-enriched F-1 cells survived and developed only in the presence of muscle cells or in muscle-conditioned medium on highly adhesive substrata. Large, multipolar neurons predominated under these conditions. The method described provides a means of characterizing the factors involved in the development of distinct populations of cells from the embryonic spinal cord.
\end{abstract}

The most complex example of the control of morphogenesis may be the development of the vertebrate nervous system, where a few thousand similar stem cells give rise to billions of cells and dozens of different cell types, all in an extremely complex, yet highly specific functional and morphological array (Jacobson, 1978). Several im-

\footnotetext{
${ }^{1}$ This research was performed during the tenure of postdoctoral fellowships (R. L. S. and A. E. S.) from The Muscular Dystrophy Association. We are grateful to Dr. Marshall Nirenberg and Dr. Mathew P. Daniels in whose laboratories the work was completed. We also wish to acknowledge Ms. Lisa Chang for aid in preparing the micrographs, Dr. Mary Ellen Michel for aid in tetanus toxin histochemistry, and Mrs. Mary Riggin for manuscript preparation.

${ }^{2}$ To whom all correspondence should be directed at his present address: Department of Pharmacology and Experimental Therapeutics, The Johns Hopkins University, 725 North Wolfe Street, Baltimore, MD 21205.
}

portant morphogenic features of this process have been defined at the cellular level and these include cell proliferation, differentiation, migration, growth, and death. A large body of information from experimental embryology suggests that specific interactions between cells, either by direct contact or via humoral factors, influence all of these features. Thus, the fate of a developing neuron may be determined by interactions with other neurons, with glia, or with peripheral target cells (Varon and Bunge, 1978). The identification of the cellular and ultimately the chemical signals which control the developmental fate of neurons remains a major challenge in the neurosciences.

Trophic influences have been well established for the effect of muscle (peripheral target) on the development of the corresponding motoneurons (Weiss et al., 1945; Cavanaugh, 1951). Neuroanatomical studies (Chu-Wang and Oppenheim, 1978a, b, and c) have established that: 
(1) There is an excess of motoneurons produced in the lateral motor column of the developing spinal cord. (2) At the time of innervation, death of a large portion of the motoneurons normally occurs resulting in a close correlation between the number of motoneurons and myofibers. (3) Removal of the peripheral field causes more extensive and more rapid death of the corresponding motoneurons. (4) Addition of peripheral field (e.g., via limb graft) causes a decrease in motoneuron death. These data support the hypothesis that proliferation, differentiation, and motility of motoneurons is initially independent of the peripheral field, but the peripheral field is essential for further development and the maintenance of cell viability.

Although neuroanatomical studies have been revealing, there are mechanistic questions which remain unsolved for technical reasons. Motoneurons in the experiments referred to above remain in intimate apposition to other neurons and glia, as well as to the cells in the peripheral field. Thus, it is impossible to establish the role of each cell type in the nurture of the motoneuron. In addition, the complexity of the in vivo situation severely hinders biochemical investigations of the trophic factors. For this reason, investigators have used cell culture to simplify the problem (Meyer et al., 1979; Giller et al., 1977; Berg, 1978).

Cells dissociated from embryonic nerve tissues retain many of their morphological and biochemical characteristics. Tissue explants and cells dissociated from several nerve tissues, including spinal cord, have been successfully maintained in vitro, and the properties of both glial and neuronal cells have been described (Fischbach and Nelson, 1977; Patrick et al., 1978). The neurons in these preparations attach to artificial substrata, extend long processes, have excitable membranes, respond to many neurotransmitters and drugs, and form morphological and functional synapses with each other and with target cells in vitro (Ransom et al., 1977; Nelson et al., 1978). Since muscle cells, as well as spinal cord neurons, can be maintained readily in cell culture, this system provides a unique opportunity to evaluate the effect of target cells on neuronal development. Giller et al. $(1973,1977)$ reported a distinct positive trophic effect of muscle cells on the development of cholinergic enzyme activity in mouse embryonic spinal cord cells in culture. Other workers have reported the lack of such an effect (Berg, 1978). A possible explanation for the discrepancies comes from the work of Meyer et al. (1979) who demonstrated a positive trophic effect of muscle on cholinergic activity of dissociated spinal cord neurons, but no such effect on spinal cord explants. Thus, the effects of other neurons or glia on the cholinergic neurons may obscure the trophic effects of the target cell. A complete investigation of the various potential trophic inputs to cholinergic cells in the spinal cord could be made possible by the separation of the cholinergic cells from other cell types in the spinal cord, followed by in vitro culture in various combinations. These studies would require the preparation of purified cholinergic spinal cord neurons in amounts suitable for biochemical evaluation of their in vitro differentiation. While methods have been published to this end (Berg and Fischbach, 1978; Masuko et al., 1979), relatively small percentages of the cholinergic neurons were retrieved, and the methods had other significant drawbacks. The present study was undertaken to generate a simple, rapid, and effective method to recover considerably greater numbers of the cholinergic cells from embryonic spinal cord of both chick and rat. The method involves the separation of different cell populations based on their different buoyant densities, using iso-osmotic metrizamide density gradients. The resulting separated populations were morphologically and biochemically distinct and demonstrated remarkable differences in in vitro growth characteristics. Evidence is presented that the cholinergic subpopulation may be dependent on muscle cells, either directly or indirectly, for their viability and/or cholinergic expression. In addition, the method provides a means for isolating and characterizing other subpopulations of neurons from the spinal cord.

\section{Materials and Methods}

The following chemicals were purchased from the indicated sources: metrizamide (2-(3-acetamido-5- $N$-methylacetamido-2,4,6-triiodobenzamido) -2-deoxy-D-glucose), Accurate Chemical and Scientific Corp., Westbury, NY; trypsin (TRL 3), Worthington Biochemical Corp.; DNase I, NADH, and polylysine (P-1886), Sigma Chemical Co.; acetyl coenzyme A, Calbiochem; and acetyl-1$\left[{ }^{14} \mathrm{C}\right]$ acetyl coenzyme A (NEC- $\left.313,48.3 \mathrm{mCi} / \mathrm{mmol}\right)$ and scintillation fluor (Aquasol), New England Nuclear.

\section{Buffers and media}

Buffer 1. Buffer 1 contained (per liter): $8.0 \mathrm{gm}$ of sodium chloride, $0.2 \mathrm{gm}$ of potassium chloride, $0.2 \mathrm{gm}$ of potassium phosphate (monobasic), $2.16 \mathrm{gm}$ of sodium phosphate (dibasic heptahydrate), and $1 \mathrm{gm}$ of glucose.

Buffer 2. Buffer 2 contained (per liter): $5.96 \mathrm{gm}$ of HEPES (4-(2-hydroxyethyl)-1-piperazineethanesulfonic acid), $0.84 \mathrm{gm}$ of sodium carbonate, $0.14 \mathrm{gm}$ of sodium phosphate monobasic monohydrate, $0.40 \mathrm{gm}$ of potassium chloride, $1.01 \mathrm{gm}$ of glucose, $7.88 \mathrm{gm}$ of sodium chloride, $0.26 \mathrm{gm}$ of calcium chloride dihydrate, and 0.2 gm of magnesium sulfate heptahydrate. The solution was adjusted to $\mathrm{pH} 7.4$ by addition of $1 \mathrm{M}$ of sodium hydroxide. The final osmolarity was $340 \mathrm{mOsm} / \mathrm{liter}$.

Lysis buffer. Lysis buffer contained (per liter): $14.6 \mathrm{gm}$ of sodium chloride, $6.8 \mathrm{gm}$ of potassium phosphate (monobasic), 0.15 gm of ethylenediaminetetraacetate (EDTA), and $5 \mathrm{ml}$ of Triton X-100. The solution was adjusted to $\mathrm{pH} 7.4$ using $1 \mathrm{~m}$ potassium hydroxide.

Medium A. Medium A consisted of Dulbecco's minimal essential medium (DMEM) (GIBCO No. 430-2100) supplemented with $0.37 \mathrm{gm} /$ liter of sodium bicarbonate and $2.4 \mathrm{gm} / \mathrm{liter}$ of HEPES. The solution was adjusted to $340 \mathrm{mOsm} / \mathrm{liter}$ and $\mathrm{pH}$ 7.4.

Medium B. Medium B consisted of DMEM (GIBCO No. 430-2100) supplemented with $3.7 \mathrm{gm} / \mathrm{liter}$ of sodium bicarbonate (340 mOsm/liter, $\mathrm{pH} 7.4)$.

Medium C. Medium C consisted of minimal essential medium (MEM) (GIBCO No. 420-1100) supplemented with $3.7 \mathrm{gm} /$ liter of sodium bicarbonate and $5 \mathrm{gm} / \mathrm{liter}$ of additional glucose ( $340 \mathrm{mOsm} /$ liter, $\mathrm{pH} 7.4$ ).

As indicated in the text, some of the media were supplemented with the following: fetal bovine serum 
(FBS) (North American Biologicals), horse serum (HS) (National Institutes of Health, complement inactivated via incubation at $56^{\circ} \mathrm{C}$ for $30 \mathrm{~min}$ ), and/or chick embryo extract (CEE) (50\%, GIBCO).

Metrizamide stock solution. Metrizamide stock solution was prepared by dissolving $38 \mathrm{gm}$ of metrizamide in enough water to make $100 \mathrm{ml}$ of solution. Solutions of various densities were prepared by mixing metrizamide stock solution with Medium A. The osmolarity of the resulting dilutions ranged from 340 to $350 \mathrm{mOsm} / \mathrm{liter}$.

\section{Assay procedures}

Density of metrizamide solutions. Densities of metrizamide solutions or gradient fractions were routinely determined by relating the refractive index (measured using an Abbe refractometer, American Optical Corp.) to an empirically determined equation:

$$
\delta=\left(n_{D}-1.0423\right) \times 3.426 .
$$

Cell counting and viability. The concentration of cells in various fractions was assessed using a hemocytometer. At least 200 cells were counted for each determination, and each value is the mean of duplicate or triplicate determinations. The dye trypan blue was added to the counting suspensions at a concentration of $0.2 \%(\mathrm{w} / \mathrm{v})$ and viability was defined as exclusion of the dye.

Lactate dehydrogenase (LDH) assay. Assays were performed on aliquots of cell lysates (see below) as described previously (Schnaar et al., 1978). To $0.5 \mathrm{ml}$ of 0.1 M potassium phosphate buffer ( $\mathrm{pH} 7.0)$ in a 1-ml quartz cuvette was added $25 \mu \mathrm{l}$ of sample consisting of cell lysate and/or lysis buffer. Cell lysates were kept frozen until the time of assay, and assays were performed within $5 \mathrm{~min}$ of thawing to avoid loss of enzyme activity. To the diluted sample in the cuvette was added $0.45 \mathrm{ml}$ of a solution containing $0.1 \mathrm{~m}$ potassium phosphate buffer ( $\mathrm{pH} 7.0$ ), $4.2 \mathrm{~mm}$ sodium pyruvate, and $0.45 \mathrm{~mm} \mathrm{NADH}$. The samples were mixed briefly, and the decrease in absorbance at $340 \mathrm{~nm}$ was periodically recorded using a Beckman DU spectrophotometer and a Gilford multiple sample absorbance recorder. The measured rate was linear for at least $5 \mathrm{~min}$ and was proportional to the amount of cell lysate added.

Choline acetyltransferase (CAT) assay. The assay used measured the transfer of radiolabel from $\left[{ }^{14} \mathrm{C}\right]$ acetyl coenzyme A (CoA) to acetylcholine as previously published (Schrier et al., 1974). Cell lysates (see below) were kept frozen on dry ice no more than $24 \mathrm{hr}$ prior to assay. At the time of assay, the lysates were thawed at room temperature, an aliquot (up to $40 \mu \mathrm{l}$ ) was placed in an ice cold glass test tube, and the volume was adjusted to 40 $\mu \mathrm{l}$ by addition of lysis buffer. A $10-\mu$ l aliquot of assay solution containing $12.5 \mathrm{~mm}$ choline chloride, $0.5 \mathrm{mM}$ neostigmine methylsulfate, $1.1 \mathrm{mM}$ acetyl $\mathrm{CoA}$, and 5 $\mu \mathrm{Ci} / \mathrm{ml}$ of $\left[{ }^{14} \mathrm{C}\right]$ acetyl $\mathrm{CoA}$, all in lysis buffer, was added, and the tubes were transferred to a $37^{\circ} \mathrm{C}$ water bath for $10 \mathrm{~min}$. After the incubation, $1 \mathrm{ml}$ of ice cold water was added, the tubes were mixed, and the diluted solutions were applied to disposable columns containing $1 \mathrm{ml}$ of AG 1-X8 anion exchange resin (100 to 200 mesh, Bio-Rad Laboratories). The column was washed with $2 \mathrm{ml}$ of ice cold water, the effluents were combined, $10 \mathrm{ml}$ of scintil- lation fluor were added, and radioactivity was determined using a liquid scintillation spectrometer. The reaction rate was linear with time up to $20 \mathrm{~min}$ and was linearly proportional to the amount of cell lysate added.

\section{Spinal cord dissociations}

Chick embryo spinal cord cells were prepared from white Leghorn chick embryos (Truslow Farms, Inc., Chestertown, MD) at 6 to 7 days of gestation (Hamburger-Hamilton (1951) stages 30 to 32 ) by previously reported methods (Fischbach and Nelson, 1977). Spinal cords were dissected sterilely from surrounding tissue, stripped of dorsal root ganglia, and placed in ice cold Medium A (14 ml). Six to 16 cords were combined for each preparation. The intact cords were collected by centrifugation $(50 \times \mathrm{g}, 2 \mathrm{~min})$, resuspended in $14 \mathrm{ml}$ of ice cold Buffer 1, again collected by centrifugation, and resuspended in $5 \mathrm{ml}$ of Buffer 1 supplemented with 0.5 $\mathrm{mg} / \mathrm{ml}$ of trypsin and $0.05 \mathrm{mg} / \mathrm{ml}$ of DNase I. The spinal cords in trypsin solution were incubated at $37^{\circ} \mathrm{C}$ for 17.5 min with intermittent agitation. The dissociation was stopped by addition of $1 \mathrm{ml}$ of fetal bovine serum, the suspension was chilled on ice, triturated 20 times with a 5 -ml plastic pipette, and centrifuged at $225 \times g$ for 10 min at $4^{\circ} \mathrm{C}$. The pellet was resuspended by trituration (20 times) in 2 to $2.5 \mathrm{ml}$ of ice cold Medium A (with 0.05 $\mathrm{mg} / \mathrm{ml}$ of DNase I), and centrifuged at $4 \times g$ for $5 \mathrm{~min}$ at $4^{\circ} \mathrm{C}$ to remove any large aggregates. The supernatant, containing the desired cells, was transferred to a fresh tube and maintained at $0^{\circ} \mathrm{C}$ until used (less than $60 \mathrm{~min}$ ). This procedure yielded $3.5 \pm 0.9 \times 10^{6}$ cells per spinal cord, $95 \pm 2.5 \%$ single cells, and $98 \pm 1.1 \%$ viability (mean $\pm \mathrm{SD}, n=12$ ).

Rat embryonic spinal cord cells were prepared in a similar manner. Embryos were collected from SpragueDawley rats (Taconic Farms, Germantown, NY) at 12 days of gestation. Dissected cords were stripped of meninges and dorsal root ganglia and placed in ice cold Medium A. Several cords (9 to 12) were combined for each experiment. Cells were prepared as above, except that the dissociation mixture consisted of $0.2 \mathrm{mg} / \mathrm{ml}$ of trypsin and $0.1 \mathrm{mg} / \mathrm{ml}$ of DNase $I$ in Buffer 1 . This procedure yielded approximately $4.3 \pm 0.8 \times 10^{6}$ cells per cord, $95 \pm 2.0 \%$ single cells, and $86 \pm 8.0 \%$ viability. The cell suspension was kept ice cold until used.

No antibiotics were used in any phase of cell preparation or in vitro cell culture. All solutions were sterilized via filtration before use when cell culture was intended ( $0.22 \mu \mathrm{m}$ porosity cellulose acetate, Millipore Corp.).

\section{Density centrifugation of spinal cord cells}

Continuous metrizamide density gradients were used for the analytical determination of the densities of isolated spinal cord cells. Discontinuous (step) gradients were used for preparative fractionation of cell types for in vitro growth.

Continuous gradients. Linear iso-osmotic density gradients $(1.01$ to $1.10 \mathrm{gm} / \mathrm{ml})$ were prepared in $12-\mathrm{ml}$ glass centrifuge tubes (Sorvall) using a density gradient mixer (Buchler). Since these gradients were used for analytical purposes only, sterility was not maintained. A $0.5-\mathrm{ml}$ aliquot of a 1:1 mixture of Medium A and metrizamide 
stock solution was placed first in the bottom of each tube as a cushion. In the chambers of the gradient maker were placed solutions of metrizamide stock solution and $\mathrm{Me}-$ $\operatorname{dium} \mathrm{A}$ as follows. The heavier solution contained a mixture of 1 part metrizamide stock solution plus 1.73 parts Medium A (13.9\% metrizamide (w/v), final concentration). The light solution contained a mixture of 1 part metrizamide stock solution plus 19.2 parts Medium A (1.9\% metrizamide $(\mathrm{w} / \mathrm{v})$, final concentration). For each gradient being formed, $5 \mathrm{ml}$ of the heavy solution was added to chamber 1 of the gradient maker along with a magnetic stir bar. Light solution was added to chamber 2 of the gradient maker until the hydrostatic pressure was equalized between the chambers (approximately 5.25 $\mathrm{ml} /$ tube) and linear gradients were formed by pumping solution out of the gradient maker using a peristaltic pump at a flow rate of approximately $0.5 \mathrm{ml} / \mathrm{min} / \mathrm{tube}$. The gradients were chilled in an ice water bath before addition of cell suspensions.

Discontinuous (step) gradients. Metrizamide stock solution and Medium A were mixed in various combinations to produce the densities described in the text below. The density of each solution was determined based on the refractive index. These solutions were then sterilized by filtration. To a sterile $12-\mathrm{ml}$ glass centrifuge tube (Sorvall) was added a cushion consisting of $0.5 \mathrm{ml}$ of a 1:1 solution of metrizamide stock solution and Medium A. The gradients consisted of three steps with densities (grams per milliliter) of 1.035 (6.4\% metrizamide), 1.050 (9.3\% metrizamide), and 1.070 ( $13.6 \%$ metrizamide) for chick spinal cord cell fractionation. For rat spinal cord cell fractionation, steps having densities (grams per milliliter) of $1.048,1.064$, and 1.090 were used. The gradient steps were conveniently produced by adding each density solution (heaviest first) to the tube through a sterile disposable $12-\mathrm{ml}$ syringe body fitted with a 20 gauge sterile disposable needle placed such that the solutions flowed slowly down the wall of the centrifuge tube via gravity. In this way, distinct density steps were produced rapidly and sterilely. The tube was covered with a sterile (ethanol-rinsed) polypropylene cap. Gradients were chilled in an ice water hath before addition of cell suspensions.

Centrifugation and recovery of cells. In order to avoid cell-cell adhesions from occurring before the fractionation of the cell types was accomplished, all procedures were performed at 0 to $4^{\circ} \mathrm{C}$ in the absence of serum. Ice cold cell suspension ( 1.5 to $2.5 \mathrm{ml}$ in Medium A) was gently introduced along the wall of the centrifuge tube containing the desired gradient. The tubes were then subjected to centrifugation at $2500 \times g$ for 12.5 to $15 \mathrm{~min}$ at $4^{\circ} \mathrm{C}$ in a Sorvall RC-2 centrifuge fitted with an HB-4 swinging bucket rotor. No braking was applied during deceleration.

Continuous gradients were fractionated from the bottom of the tube (via gravity) into $12 \times 75 \mathrm{~mm}$ glass test tubes $(0.5 \mathrm{ml} /$ fraction). Aliquots $(25 \mu \mathrm{l})$ were removed for measurement of refractive index for density determination. Ice cold Medium A (3 ml) then was added to each fraction, the tubes were gently agitated, and the cells were collected by centrifugation $(650 \times g, 15 \mathrm{~min})$. For determination of enzyme activities in the recovered frac- tions, supernatant media were decanted and $100 \mu \mathrm{l}$ of lysis buffer were added to each cell pellet. The lysates were mixed briefly and frozen in an acetone/dry ice bath. Tubes were stored on dry ice until the enzyme assays were performed.

Centrifugation of cells on step gradients resulted in the formation of turbid bands of cells at the step interfaces (Fig. 1). Each band was removed with a sterile pipette and added to $10 \mathrm{ml}$ of ice cold Medium $A$ in a $15-\mathrm{ml}$ sterile plastic centrifuge tube. The tubes were gently agitated to dilute the metrizamide, and the cells were collected by centrifugation at $650 \times \mathrm{g}$ for $10 \mathrm{~min}$ at $4^{\circ} \mathrm{C}$. Cell fractions were resuspended in appropriate media for cell culture or for determination of cell number, enzyme activities, etc., as outlined elsewhere in the text. Aliquots of the unfractionated cells (maintained on ice during the gradient centrifugation) were resuspended and centrifuged in parallel with the isolated fractions. Subsequent assay procedures were performed on the unfractionated cells, as well as the isolated fractions, for comparison.

\section{Cell culture}

Cells were grown in either $35-\mathrm{mm}$ tissue culture dishes (Falcon No. 3001) or in multiple well tissue culture plates (Costar No. 3524, 24 wells). In most experiments (as indicated), the surfaces were pretreated using one or both of the following protocols: (1) Collagen layers were applied by the addition and removal of a sterile solution of collagen $(0.5 \mathrm{mg} / \mathrm{ml}$ of calf skin collagen (Calbiochem) in $0.1 \%$ acetic acid), followed by drying at $60^{\circ} \mathrm{C}$ for $1 \mathrm{hr}$. (2) Polylysine coating (Yavin and Yavin, 1974) was accomplished by adding a solution of polylysine $(5 \mu \mathrm{g} / \mathrm{ml}$ in water) to the surfaces $(1 \mathrm{ml} / 35$-mm dish) and incubating for $60 \mathrm{~min}$ at ambient temperature. All surfaces were washed with Medium A before cells were introduced.

Cell culture was performed in a humidified atmosphere of $10 \% \mathrm{CO}_{2}, 90 \%$ air at $36.5^{\circ} \mathrm{C}$.

Muscle cell culture and collection of conditioned medium. Chick embryo myoblasts were prepared by trypsinization (Bischoff and Holtzer, 1968). Pectoral muscle was dissected sterilely from two or three chick embryos at 12 days gestation, minced, suspended in $5 \mathrm{ml}$ of Buffer 1 containing $2 \mathrm{mg} / \mathrm{ml}$ of trypsin and $0.05 \mathrm{mg} / \mathrm{ml}$ of DNase $\mathrm{I}$, and incubated at $37^{\circ} \mathrm{C}$ for $20 \mathrm{~min}$. After the incubation was complete, $2.5 \mathrm{ml}$ of Medium B supplemented with

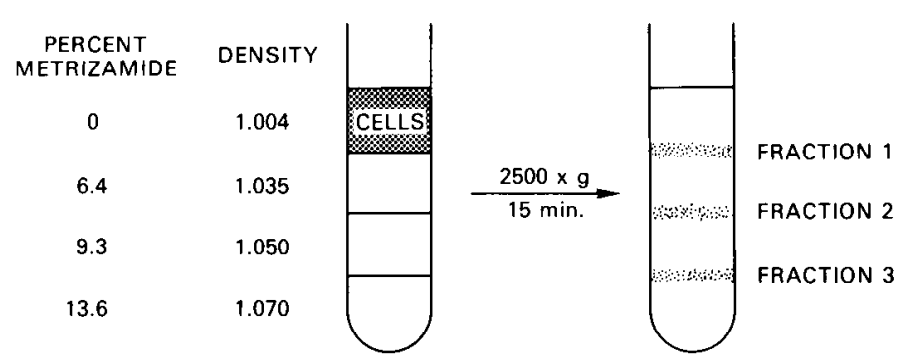

Figure 1. Schematic representation of discontinuous density gradient centrifugation of dissociated spinal cord cells. The densities and percentages of metrimazide are given for chick spinal cord fractionation. These values differ for the rat preparation (see text). Fraction number designations are the same for both chick and rat spinal cord cell fractionations. 
$10 \%$ fetal bovine serum was added, and the cells were collected by centrifugation at $180 \times g$ for $4 \mathrm{~min}$ at ambient temperature. The pellet was resuspended in 7 ml of complete chick muscle medium (containing $39 \%$ Medium B, 39\% Medium C, $10 \%$ fetal bovine serum, $10 \%$ horse serum, and $2 \%$ chick embryo extract). The cells were triturated 20 times and incubated for $45 \mathrm{~min}$ in a $100-\mathrm{mm}$ tissue culture dish under culture incubation conditions. This incubation helped to deplete the cell population of fibroblasts which adhere more readily to the dish. Nonadherent cells were collected by gentle agitation. Cell clumps were removed by filtration through $130-\mu \mathrm{m}$ Nitex screen, and the cell number was counted using a hemacytometer. The suspension (containing 3 to $6 \times 10^{7}$ cells) then was adjusted to a concentration of $10^{6}$ cells $/ \mathrm{ml}$ in complete chick muscle medium. One milliliter of cell suspension was added to each of several collagencoated 35-mm tissue culture dishes. After $24 \mathrm{hr}$ of culture, the medium was replaced with $1 \mathrm{ml}$ of complete chick muscle medium. On the 2 nd day (at which time, myoblast fusion was beginning), the medium was replaced with 1.5 ml of Medium C supplemented with $10 \%$ horse serum, $2 \%$ chick embryo extract, $10 \mu \mathrm{M}$ fluorodeoxyuridine, and $100 \mu \mathrm{M}$ uridine, to deplete dividing cells. On the 4 th and again on the 6 th day, the medium was replaced with 1.5 $\mathrm{ml}$ of Medium $\mathrm{C}$ supplemented with $10 \%$ horse serum and $2 \%$ chick embryo extract. The plates then were fed every 4 th day thereafter with the same medium. The plates, which contained primarily well differentiated myotubes with some fibroblasts present, were maintained for up to 1 month in this manner. Conditioned medium was collected at the time of medium replacement, centrifuged $(200 \times g, 5 \mathrm{~min})$, and passed through a $0.22-\mu \mathrm{m}$ Millipore filter before use. In some experiments, conditioned medium was stored at $-20^{\circ} \mathrm{C}$ for up to 2 weeks before use.

Rat myotubes were prepared by the same procedure with the following adjustments: (1) Minced thigh muscle from newborn rat pups was used. (2) Trypsinization was performed for $30 \mathrm{~min}$ at $37^{\circ} \mathrm{C}$. (3) Media contained no chick embryo extract. (4) Cells were plated at a concentration of $3.5 \times 10^{5}$ cells $/ \mathrm{ml}$. (5) Three to 4 days after plating, the medium was replaced with Medium $\mathrm{C}$ supplemented with $10 \%$ horse serum and $10 \mu \mathrm{M}$ cytosine arabinoside. After an additional 2 days, the medium was replaced with Medium C supplemented with $10 \%$ horse serum and the cultures were fed every 2 days with the same medium.

The clonal myogenic cell line, G-8, has been described previously (Christian et al., 1977). Cells were plated $(50,000$ cells/plate $)$ in collagen-coated $35-\mathrm{mm}$ dishes in Medium $\mathrm{B}$ and supplemented to select for myotube fusion as follows: days 1 to $3,10 \%$ fetal bovine serum (FBS); days 3 to $7,0.5 \%$ FBS $+5 \%$ horse serum (HS); days 7 to $9,0.5 \% \mathrm{FBS}+5 \% \mathrm{HS}+10 \mu \mathrm{M}$ fluorodeoxyuridine +100 $\mu \mathrm{M}$ uridine; day 9 and thereafter, $0.5 \% \mathrm{FBS}+5 \% \mathrm{HS}$ (replaced every 3rd day). The resulting cultures were crowded with myotubes, with only a small percentage of myoblasts present.

Spinal cord cell culture. Spinal cord cells were routinely maintained on collagen-treated plates in Medium C supplemented with $10 \%$ fetal bovine serum, $10 \%$ horse serum, and $2 \%$ chick embryo extract (chick cells only). When muscle-conditioned medium was used, $10 \%(\mathrm{v} / \mathrm{v})$ FBS was added. Media was replaced every 3 to 4 days. For determination of CAT activity, cells were scraped from the surface of the plates with a glass rod, transferred to a ice-chilled $12 \times 75 \mathrm{~mm}$ glass test tube, and $1.5 \mathrm{ml}$ of Buffer 2 was added. The tubes were centrifuged at 500 $\times g$ for $15 \mathrm{~min}$, the supernatant was discarded, and cell pellets were lysed by addition of $100 \mu$ l of lysis buffer. Lysates were kept frozen on dry ice for up to $24 \mathrm{hr}$ before enzyme assays were performed.

\section{Results}

\section{Linear Density Gradient (Analytical) Fractionation}

To assess the use of equilibrium density centrifugation as a tool for the purification of cholinergic cells from the spinal cord, dissociated spinal cord cells were centrifuged on linear, metrizamide density gradients. The distribution of cells on the gradient was measured using two enzyme assays. Lactate dehydrogenase activity was used as a general cell marker, since $\mathrm{LDH}$ is widely distributed in mammalian and avian cells. Choline acetyltransferase activity was used as a specific marker for cholinergic cells. The described procedure measures enzymes only from intact cells, since: (1) cells isolated from the gradient are washed (by centrifugation) in a relatively large volume of Medium A before lysis for enzyme assays and (2) the measured enzymes are soluble and are readily released from broken cells during the washing procedure. Thus, the data reflect the recovery, at any particular density, of intact cells containing the appropriate enzymes.

The data in Figure 2 demonstrate the distribution of the enzyme markers on linear metrizamide gradients. Cells from both chick and rat embryo spinal cord distribute in a broad, irregular peak over the density range 1.02 to $1.09 \mathrm{gm} / \mathrm{ml}$. The mean cell density of chick cells is $1.051 \mathrm{gm} / \mathrm{ml}$ and that of rat cells is $1.049 \mathrm{gm} / \mathrm{ml}$. The cholinergic cells do not distribute in the same manner, but band in a much narrower peak at lower average densities. The mean cholinergic cell density of chick cells is $1.032 \mathrm{gm} / \mathrm{ml}$ and that of rat cells is $1.035 \mathrm{gm} / \mathrm{ml}$. A remarkable similarity between the density profiles for cells from rat and chick embryos at similar developmental stages is apparent.

The distinct banding of cholinergic cells at lower buoyant densities than the bulk of the cells in the population was used for preparative isolation of a cholinergic-enriched cell fraction.

\section{Step Gradient (Preparative) Fractionation}

Linear gradients provide excellent resolution for analytical determinations, however, step gradient fractionation was found to be more efficient for preparative fractionation. Therefore, the density of the cholinergic cells was estimated from the linear gradient results, and appropriate discontinuous gradients were designed (Fig. 1).

Step gradients were easy to prepare under sterile conditions, no special equipment being required. Because of the low viscosity of the iso-osmotic metrizamide solutions, the centrifugation times necessary to fractionate 


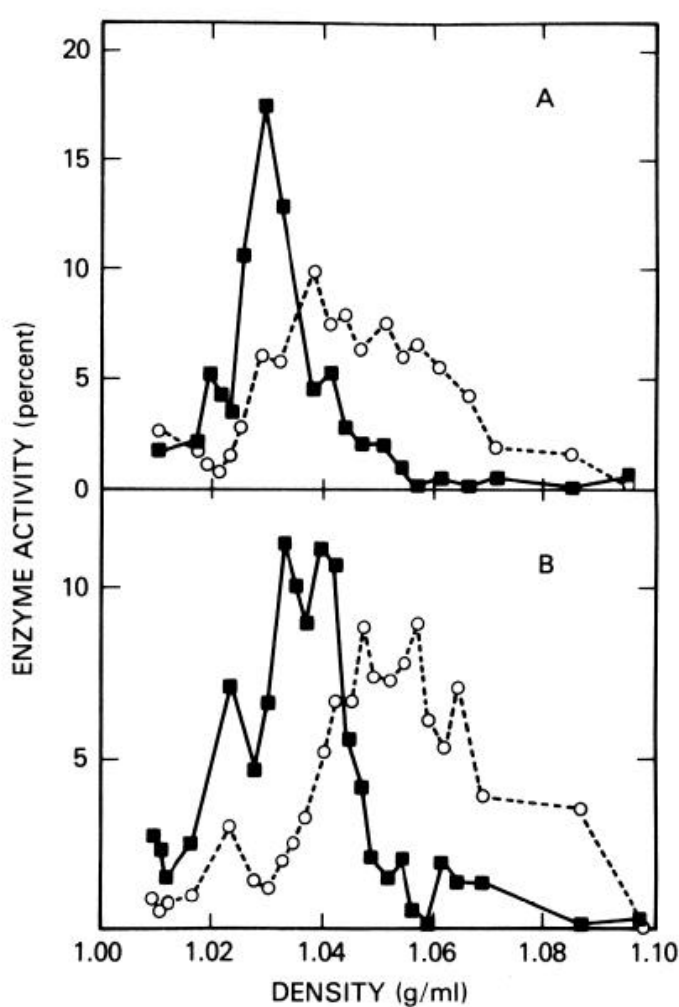

Figure 2. Fractionation of chick and rat spinal cord cells on linear metrizamide density gradients. Gradients were formed, cells were fractionated, and enzyme activities were determined as described in the text. $\mathbf{\square}$, choline acetyltransferase activity; $\bigcirc$, lactate dehydrogenase activity. $A$, Embryonic chick spinal cord cells; $B$, embryonic rat spinal cord cells.

the cells were very short. After 15 min of centrifugation at $2500 \times g$, cells were separated into three distinct "bands" at the step interfaces. Cells were recovered by drawing off 1.5 to $2.0 \mathrm{ml}$ of cells and medium at each interface with a sterile pipette. The cell suspension was diluted immediately with 5 to $10 \mathrm{vol}$ of Medium A, without considerable cell damage, since there was no osmotic shift upon dilution. As indicated in Figure 1, the cells recovered from the first interface were designated Fraction 1, those from the middle interface Fraction 2, and those from the third interface Fraction 3. The metrizamide concentrations in Figure 1 are given for fractionation of the chick spinal cord cells. The concentration of metrizamide in each step was slightly higher for the rat cell preparation as outlined in the legend to Figure 7.

\section{Analysis of Chick Spinal Cord Cell Fractionations}

\section{Morphology}

Aliquots of the resuspended cell fractions were photographed using phase contrast microscopy. As can be seen in Figure 3, the unfractionated dissociated chick spinal cord contains cells of various sizes and morphologies. At the magnifications used, the largest cells appear granular in the cytoplasm and have a distinct nucleus with well defined nucleoli. A population of smaller cells appear more uniformly dense. The smallest cells are highly refractile, and finer structure is below the level of reso- lution at this magnification. The morphology of the isolated fractions indicates a remarkably distinct separation of the described morphologies from each other. Quantitation from the photographs demonstrated that $20 \%$ of the unfractionated cells are the larger cells (with less refractile cytoplasm and distinct nuclei) while $86 \%$ of Fraction 1 cells, $5 \%$ of Fraction 2 cells, and essentially no Fraction 3 cells have that morphology. The other distinguishable morphological cell types are also well separated.

Segregation of different morphological cell types can also be demonstrated via measurement of the mean diameter and volume of the cells recovered. The average diameter of the unfractionated cells is $8.1 \mu \mathrm{m}$, while that of Fraction 1 cells is larger $(10.8 \mu \mathrm{m})$. Average diameters of the Fraction 2 and Fraction 3 cells are successively smaller, $7.7 \mu \mathrm{m}$ and $7.2 \mu \mathrm{m}$, respectively (Fig. 4, left).

The Student's $t$ test analysis was used to test whether the observed morphological separations were statistically significant. The mean size of the cells in each fraction was significantly different from each other fraction at a confidence level of greater than $99.5 \%$.

An independent estimate of relative cell sizes was performed using the Coulter counter (Fig. 4, right). The profiles indicate that the unfractionated cells consist of a heterogeneous population sharply skewed toward the smaller volumes. Fraction 1 cells are greatly enriched in the larger cells, while Fractions 2 and 3 are successively smaller. The average volumes of the fractions are (expressed as cubic microns): unfractionated, 362; Fraction
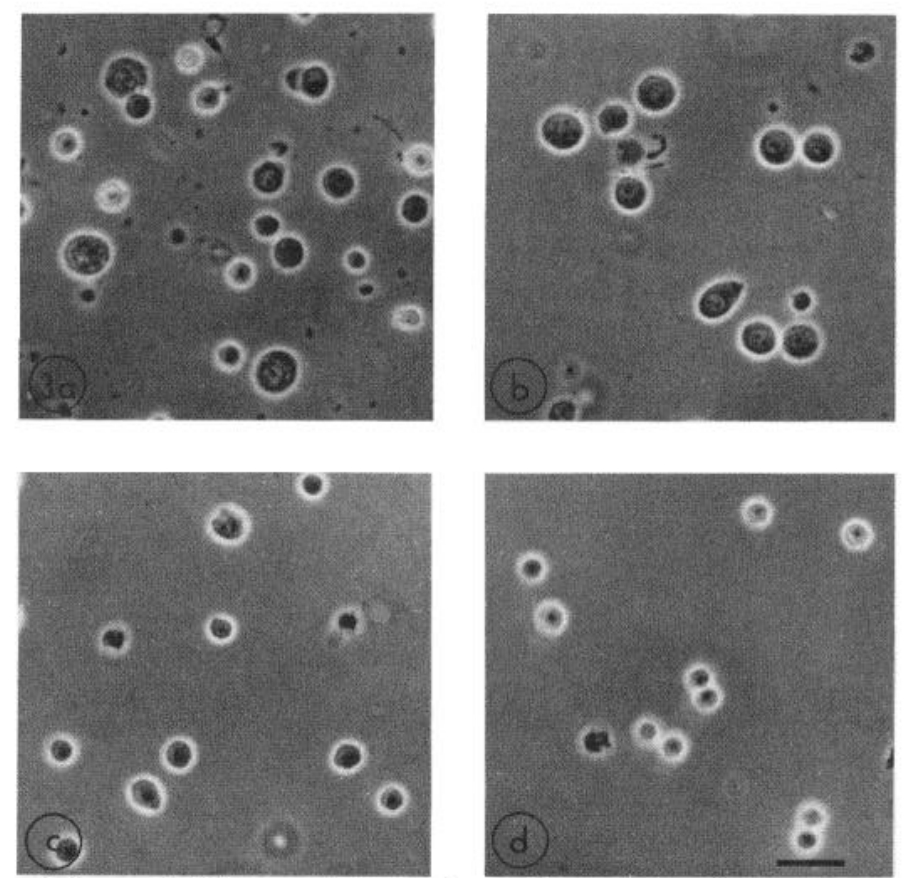

Figure 3. Phase contrast photomicrographs of dissociated chick spinal cord cells fractionated on discontinuous metrizamide gradients. Gradients were prepared and cells were fractionated as described in the text. Unfixed cells were photographed in Medium A using a Zeiss phase contrast microscope. $a$, Unfractionated cells; $b$, Fraction 1 cells; $c$, Fraction 2 cells; $d$, Fraction 3 cells. Magnification, $\times \quad 550 ;$ bar $=20 \mu \mathrm{m}$. 


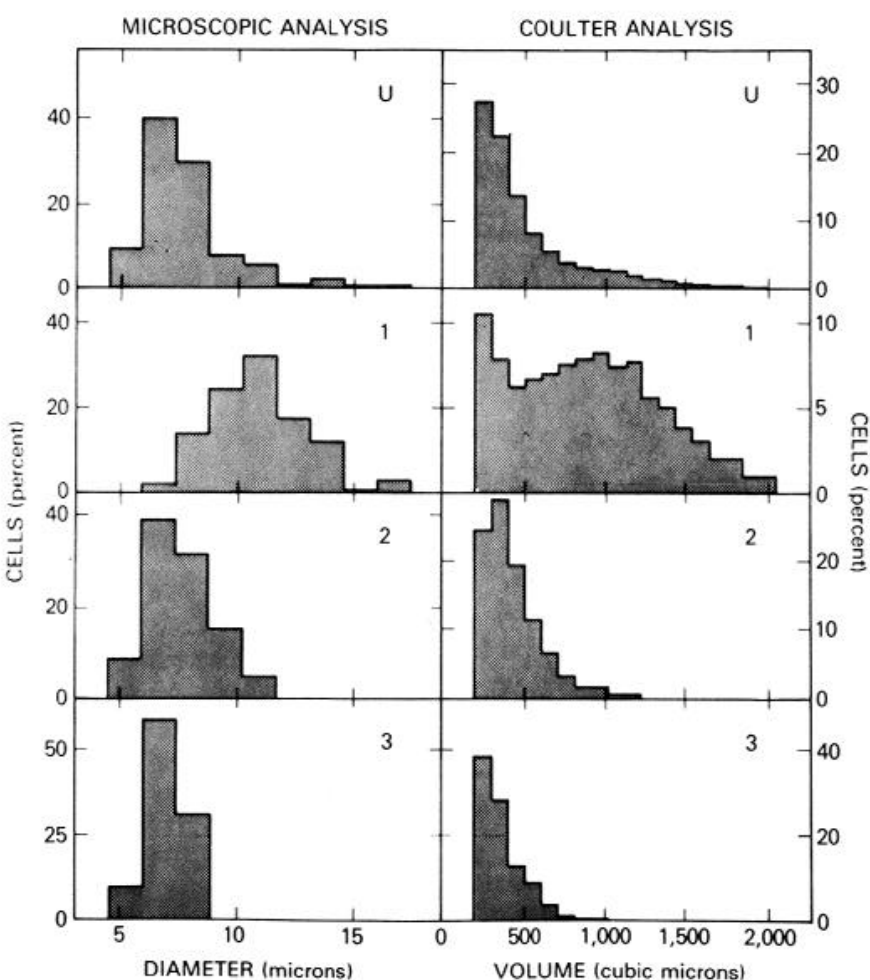

Figure 4. Size analysis of fractionated chick spinal cord cells. Gradients were prepared and cells were fractionated as described in the text. Cell diameters (left panels) were measured on photomicrographs of cells prepared as described in Figure 3. Cell volumes (right panels) were determined using a Coulter counter; unfractionated cells, or cells recovered from the gradient, were diluted to approximately $6 \times 10^{4}$ cells $/ \mathrm{ml}$ in HEPES-buffered Hank's salt solution. Samples were then subjected to analysis on a Coulter counter, using pollen of known volume for calibration. $U$, unfractionated cells; 1 to 3 , Fractions 1 to 3 isolated from gradients (see Figs. 1 and 3 ).

1, 830; Fraction 2, 348; and Fraction 3, 296. These values correspond very closely to those that would be predicted from the mean diameters obtained from the histograms in Figure 4 (left).

\section{Biochemistry}

The above data demonstrate the separation of morphologically distinct subpopulations from dissociated spinal cord cells. Biochemical data suggests that functionally distinct classes are separated as well, as shown in Table I.

Cell recovery. Greater than $80 \%$ of the cells applied to the gradient were recovered after washing and resuspension. The bulk of the cells are distributed between Fractions 2 and 3, with approximately one-sixth of the cells appearing in Fraction 1.

Viability. As measured by trypan blue exclusion, the recovered cells are almost all intact, reflecting the gentle nature of the procedures involved.

Choline acetyltransferase activity. Greater than $70 \%$ of this enzymatic activity is recovered from the gradient, with the large bulk appearing in Fraction 1. This segregation of the cholinergic cells in Fraction 1 results in about a 4-fold enrichment of cells having CAT activity in that fraction when compared to the unfractionated start- ing population. Fractions 2 and 3 are depleted in cholinergic cells, having $25 \%$ and $4.2 \%$ of the original specific activity, respectively.

A correlation was observed between morphological segregation and functional segregation. As discussed above, large nonrefractile cells are enriched about 4 -fold in Fraction 1, depleted to $25 \%$ of the original proportion in Fraction 2, and nearly absent in Fraction 3. These values correlate with the separation of CAT-containing cells, however more direct evidence that the distinct morphology represents cholinergic cells awaits further experimentation.

Lactate dehydrogenase activity. The recovered LDH (general cell marker) appears to be evenly distributed among the three fractions isolated. It should be noted that the LDH activity per cell is roughly proportional to the cell volume. The larger Fraction 1 cells, therefore, contain more LDH per cell. If the values obtained from the Coulter counter volume analysis (Fig. 4) are used to normalize the LDH values for the variation in cell size, one finds the LDH recovery data correlates very well with the cell recovery data.

These data demonstrate that the procedure outlined results in a marked segregation of morphological and functional cell types, with large cholinergic cells greatly enriched in Fraction 1. The usefulness of the procedure is greatly enhanced by both the high recovery and the high viability of cells in all of the fractions.

\section{Reproducibility of the method}

The reproducibility of the established step gradient fractionation procedure is very good. Data compiled from five experiments performed at different times using separate cell preparations and separate metrizamide solutions demonstrate that: (1) The majority of the cells are recovered from the gradient, and they remain viable; (2) while there is some variation in the distribution of cells in Fractions 2 and 3, Fraction 1 reproducibly contains about one-sixth of the cells $(16.8 \pm 3.5 \%)$; (3) the large bulk of the recovered CAT activity appears in Fraction $1(57 \pm 15 \%)$ with Fraction 2 having little of this enzyme $(7 \pm 4 \%)$ and Fraction 3 being essentially devoid $(0.7 \pm$ $0.6 \%)$. Fraction 1 is markedly enriched for the presence of cholinergic cells, Fraction 3 is nearly free of such cells, and Fraction 2 is intermediate.

\section{Analysis of Rat Spinal Cord Fractionation}

The fractionation of cells from the rat spinal cord was not as extensively studied as that from the chick spinal cord. Nevertheless, the segregation of the cells in the various fractions parallels chick spinal cord data in many ways.

\section{Morphology}

In general, the cells in Fraction 1 are larger with prominent nuclei and nucleoli and are less refractile than those in the other fractions. Fraction 2 contains some of the larger, less refractile cells, along with many smaller cells, while Fraction 3 contains mainly small, highly refractile cells. The total recovery of cells from this fractionation procedure, while better than that for other published procedures, is lower than for the chick system. 
TABLE I

Analysis of chick and rat spinal cord fractions

Embryonic chick or rat spinal cords were dissociated and $90 \%$ of the resulting cells were subjected to discontinuous density centrifugation as described in the text (the remaining $10 \%$ of unfractionated cells were retained for comparison). After density separation, turbid interface bands of cells were removed and diluted in medium, and the cells were collected by centrifugation (see "Materials and Methods"). The cell pellets were gently resuspended in Medium A, and a portion was removed for nicroscopic determination of cell number and viability. A second portion was diluted with Buffer 2, the cells were collected by centrifugation ( $650 \times \mathrm{g}, 15 \mathrm{~min}$ ), and $100 \mu$ l of lysis buffer were added. Aliquots of the lysate were used for determination of enzyme activities as described under "Materials and Methods."

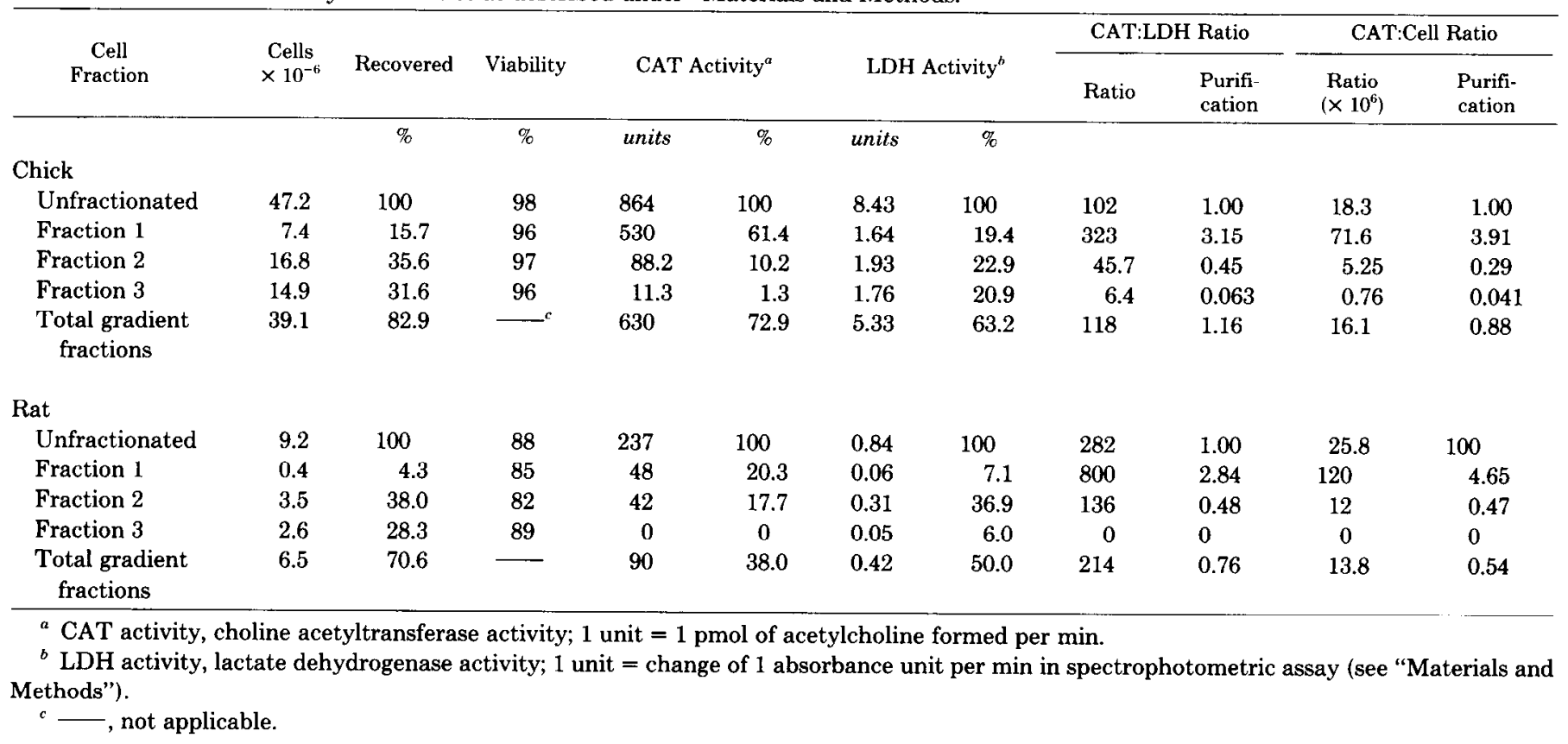

The reason for this is not understood, but may be due to the differences in the dissociation procedures necessary to prepare single cells from the rat versus the chick spinal cord (see "Materials and Methods").

\section{Biochemistry}

The biochemistry of the fractions (Table I) correlates well with the morphology and demonstrates a marked segregation of functional cell types. CAT-containing cells in this system, are distributed between Fractions 1 and 2, while Fraction 3 has no detectable CAT-containing cells. Because of the "spill" of cholinergic cells into Fraction 2, the number of cells recovered in the enriched population (Fraction 1) is relatively lower than for chick spinal cord cells, but the purification of those cells is better, yielding a 4.65 -fold enrichment over unfractionated cells.

A further indication that the cells in the different fractions from the rat spinal cord are similar to those in the parallel fractions from chick spinal cord is the similarity in their in vitro growth characteristics.

\section{Cell Culture of Fractionated Chick Spinal Cord Cells}

When cells from the various fractions are placed in culture, marked differences can be seen in their growth properties and morphologies. After a short time in culture, several clear distinctions can be made, as demonstrated by the photographs in Figure 5.

The unfractionated spinal cord cell cultures display several different cell morphologies. There are flat, nonrefractile cells which are mitosis competent and are likely to be cells of glial or mesenchymal derivation (Varon and Raiborn, 1969; Adler et al., 1979). Other cells have distinct cell bodies and extend long, often branched processes of various thicknesses. These process-bearing cells have features typical of neurons in cell culture (Skaper et al., 1979) and will be referred to as such in this paper, although an alternate designation as highly specialized glial cells cannot be ruled out.

These cells are grown under "standard" conditions, on collagen-coated surfaces in Medium $\mathrm{C}$ supplemented with $10 \%$ fetal bovine serum, $10 \%$ horse serum, and $2 \%$ chick embryo extract (chick cultures only). These conditions supported growth of both neuronal and non-neuronal cells in Fractions 2 and 3, as well as those of unfractionated spinal cords. Compared to the unfractionated cells, Fraction 2 had fewer initial non-neuronal cells (although, since they are the only dividing cells in the population, they eventually covered the bottom of the dish). There were clearly neuronal cells with highly refractile cell bodies, some of which formed small clumps and extended long thick processes. There was a minimum amount of debris from dead cells. Fraction 3 was enriched for the non-neuronal cells from the spinal cord and contained neurons primarily with dark, nonrefractile bodies, entending very thin processes over the background cells. Fraction 1, unlike the other fractions, would not persist under the conditions outlined above. Instead, these cells rapidly formed large aggregates. Soon afterward, cell death was evident and much debris appeared in the cultures (Fig. 5). Within 72 to $96 \mathrm{hr}$, no cells could be detected in the plates, indicating complete lysis. This 

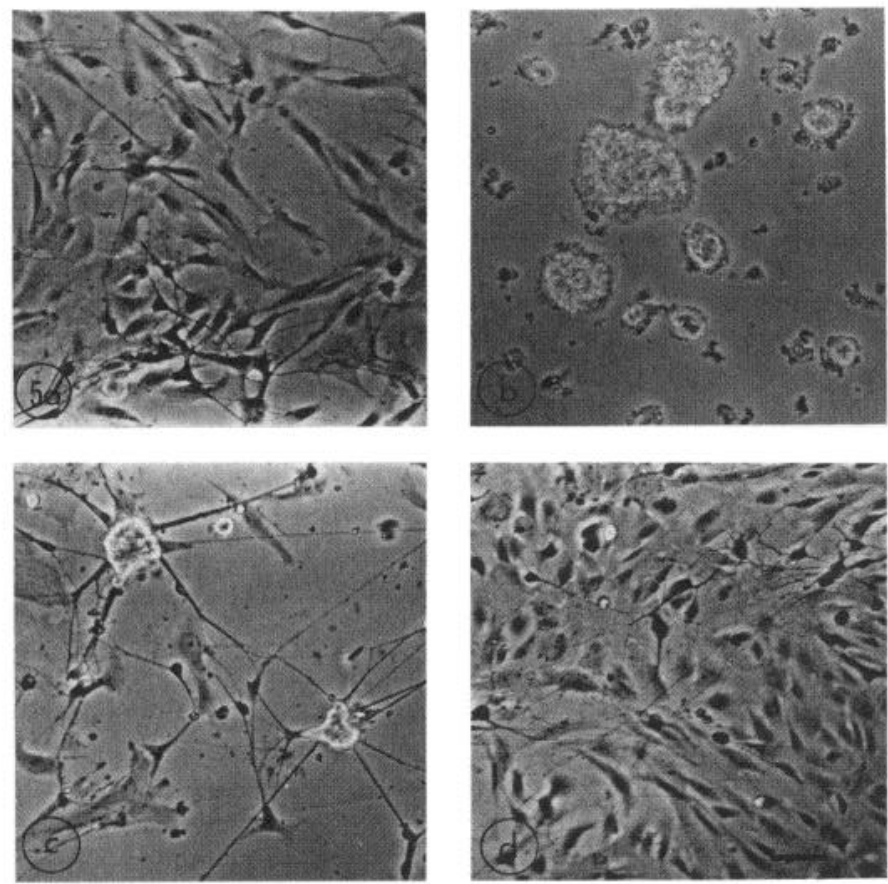

Figure 5. Morphology of unfractionated chick spinal cord cells in culture. Cells were fractionated on discontinuous gradients as described in the text and placed in culture under standard conditions described under "Materials and Methods" (35-mm collagen-coated dishes, 150,000 cells/plate in Medium C supplemented with $10 \% \mathrm{FBS}, 10 \% \mathrm{HS}, 2 \% \mathrm{CEE})$. The photomicrographs of the Fraction 1 cell culture $(b)$ were prepared after 3 days in culture. After 4 days in culture, most of the Fraction 1 cells had lysed. The other cultures were photographed after 6 days in culture. $a$, Unfractionated cells; $b$, Fraction 1 cells; $c$, Fraction 2 cells; $d$, Fraction 3 cells. Magnification, $\times \quad 450$; $b a r=20 \mu \mathrm{m}$.

effect was evidenced only in this one fraction and was essentially identical for both the rat and the chick Fraction 1 cells. Nonspecific lysis of these cells due to the fractionation procedure may not be likely, since: (1) Fraction 1 cells recovered from the gradients were impermeant to trypan blue and (2) the cells (including neurons) derived from Fractions 2 and 3 were viable, even though they had been subjected to much higher concentrations of metrizamide. For instance, Fraction 1 cells, which were collected from the interface between $0 \%$ metrizamide and $6.4 \%$ metrizamide were subjected to only half the concentration of metrizamide as Fraction 3 cells, collected from the interface between $9.3 \%$ metrizamide and $13.6 \%$ metrizamide.

In an effort to determine the conditions necessary to maintain Fraction 1 cells, two aspects of their in vitro growth were explored. The possibility that a more adhesive substrate is necessary for their maintenance was tested by using a variety of treated tissue culture surfaces. In addition, the possibility that some factor or factors derived from muscle cells improves the viability of the cholinergic Fraction 1 cells was tested by the addition of conditioned medium derived from the appropriate muscle cell cultures. Thus, in addition to the "standard" conditions described above, some plates were pretreated with polylysine to improve cell adhesion. In addition, cells were grown either in the presence or absence of muscle-conditioned medium (see "Materials and Methods"). Cultures were observed daily and scored for the presence of viable neuronal cells and the extent of neurite formation. The data from the 6 th day in culture, representative of the entire growth period, are presented in Table II. Live neurons with long neurites were observed when unfractionated, Fraction 2, or Fraction 3 cells were cultured under any of the conditions used. In marked contrast, Fraction 1 cells died within the first $96 \mathrm{hr}$ unless polylysine-coated plates were used and muscle-conditioned medium was present. Under these "optimal" conditions, the Fraction 1 cells displayed a remarkably distinct morphology (Fig. 6). There were virtually no nonneuronal cells (flattened, nonrefractile cells). The persisting neurons had large, highly refractile cell bodies, and extended extremely long and highly branched neurites. The observed morphology of the Fraction 1 cells grown under the optimal conditions is consistent with their designation as motoneurons.

Evaluation of the choline acetyltransferase activity of cholinergic cells co-cultured with muscle cells further indicates a positive trophic effect of muscle on nerve (Table III). When the cholinergic-enriched Fraction 1 cells were plated in the absence of muscle for 6 days, the CAT activity in the cultures dropped to less than $5 \%$ of its original levels. In contrast, co-culture of these cells with chick myotubes resulted in a 2 -fold increase in CAT activity. Co-culture with myotubes formed from a mouse myogenic cell line designated G8-1 (Christian et al., 1977) resulted in a depletion of CAT activity in the cultures, though not as extensive a decrease as in the absence of muscle. Although the concentration of cholinergic cells in the other fractions, or in unfractionated spinal cord cells, is much less than in Fraction 1 cells, the CAT activity in such cultures responded in a qualitatively identical manner to direct co-culture with muscle.

\section{Cell Culture of Fractionated Rat Spinal Cord Cells}

Fraction 1 cells from rat spinal cord did not survive when grown on various substrata in the presence of

TABLE II

Survival of fractionated chick spinal cord cells in culture Chick spinal cord cells were fractionated on discontinuous gradients as described in the text. Recovered cells were placed in culture on 35$\mathrm{mm}$ tissue culture dishes ( 150,000 cells/plate) in Medium C containing $10 \% \mathrm{FBS}, 10 \% \mathrm{HS}$, and $2 \% \mathrm{CEE}$. As indicated, half of the plates were pretreated with polylysine and cells were cultured in control or in muscle-conditioned medium (see "Materials and Methods"). After 6 days in culture, the cells on the plates were observed microscopically and scored for the presence of viable cells and neurites.

\begin{tabular}{lccccc}
\hline \multirow{2}{*}{$\begin{array}{c}\text { Cell } \\
\text { Fraction }\end{array}$} & \multicolumn{3}{c}{ Cell Growth (Neurite Extension) } \\
\cline { 2 - 3 } & \multicolumn{2}{c}{ Control Medium } & & $\begin{array}{c}\text { Muscle-conditioned } \\
\text { Medium }\end{array}$ \\
\cline { 2 - 3 } \cline { 5 - 6 } & - Polylysine & + Polylysine & -Polylysine & + Polylysine \\
\hline Unfractionated & $+(+)$ & $++(++)$ & $++(++)$ & $++(++)$ \\
Fraction 1 & $-a$ & - & & $+(+++)$ \\
Fraction 2 & $++(++)$ & $+(+)$ & $++(++)$ & $++(++)$ \\
Fraction 3 & $++(++)$ & $+(+)$ & $++(++)$ & $++(++)$ \\
\hline
\end{tabular}

a 


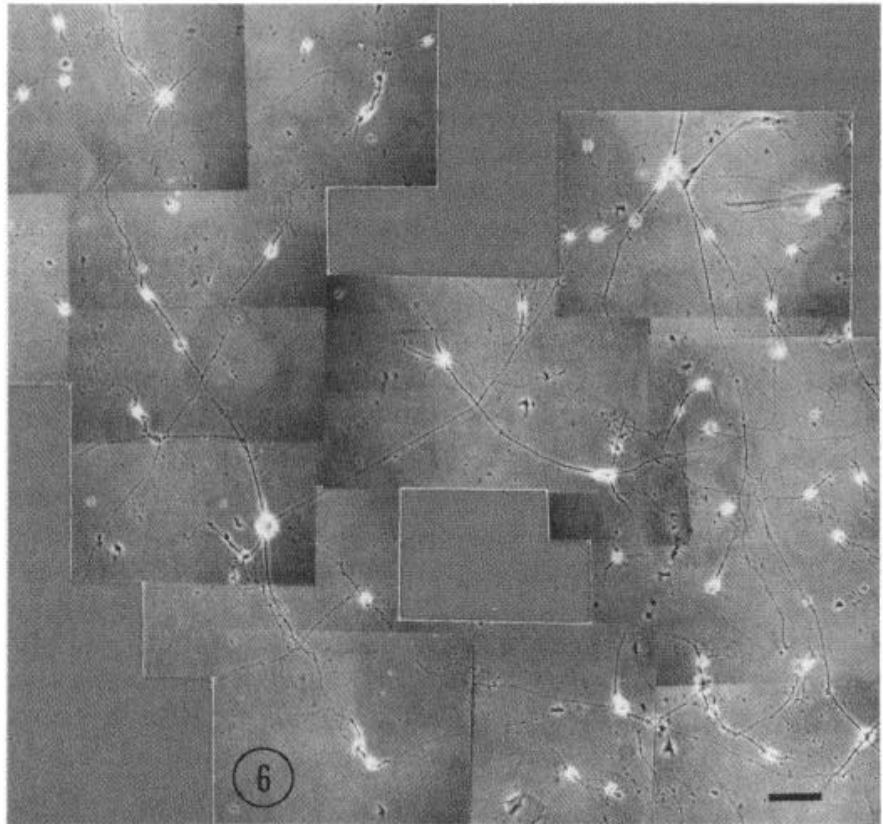

Figure 6. In vitro culture of chick spinal cord Fraction 1 cells under "optimum" conditions. Fraction 1 cells were prepared as described in the text and placed in culture $(150,000$ cells/plate) on polylysine and collagen-coated dishes in the presence of muscle-conditioned medium. Photomicrographs were prepared after 12 days in culture using a Zeiss phase contrast microscope. Magnification, $\times 160$; bar $=50 \mu \mathrm{m}$.

TABLE III

Cat activity of chick spinal cord cell fractions in co-culture with muscle cells

Chick spinal cord cell fractions were prepared as described in the text and cultured on 35-mm dishes containing well developed myotubes derived from primary chick myoblasts or clonal G8 mouse myoblasts. After 6 days in culture, cells were collected by scraping, diluted with Buffer 2, and collected by centrifugation, and the cell pellets were lysed by addition of $100 \mu \mathrm{l}$ of lysis buffer. Aliquots of the lysates were used to determine choline acetyltransferase (CAT) activity.

\begin{tabular}{lccccc}
\hline & & \multicolumn{4}{c}{ CAT Activity } \\
\cline { 3 - 6 } \multicolumn{1}{c}{$\begin{array}{c}\text { Cell } \\
\text { Fraction }\end{array}$} & $\begin{array}{c}\text { Cells per } \\
\text { Plate } \\
\left(\times 10^{5}\right)\end{array}$ & Day 0 & $\begin{array}{c}\text { Do } \\
\text { Muscle }\end{array}$ & $\begin{array}{c}\text { Chick } \\
\text { Muscle }\end{array}$ & $\begin{array}{c}\text { G8-1 } \\
\text { Mouse } \\
\text { Muscle }\end{array}$ \\
\hline & \multicolumn{4}{c}{ pmol/min/plate } \\
Unfractionated & 5.3 & 9.6 & $0.2^{a}$ & 15.6 & 1.8 \\
Fraction 1 & 4.9 & 35.4 & 1.5 & 72.9 & 15.7 \\
Fraction 2 & 11.2 & 5.9 & $0.0^{a}$ & 12.5 & 2.6 \\
Fraction 3 & 9.9 & $0.8^{a}$ & $0.9^{a}$ & 3.5 & $0.2^{a}$ \\
\hline
\end{tabular}

${ }^{a}$ Values not significantly above background.

Medium C with up to $20 \%$ serum. These substrata included dishes coated with collagen, polylysine, or with fibronectin. Similar to Fraction 1 cells from chick, Fraction 1 cells from rat grown under these conditions clumped extensively, rarely adhered to the substrate, and died within $24 \mathrm{hr}$ (Fig. 7).

As with the chick spinal cord cells, survival of Fraction 1 cells could be achieved only if the cells were plated on highly adhesive substrata in the presence of muscle-conditioned medium. Substrata were prepared according to the methods of Hawrot (Hawrot, 1980) and consisted of unfractionated embryonic rat spinal cord cultures which had been heat treated, EDTA treated, or paraformaldehyde fixed. Under these conditions, cells adhered and survived and exhibited the morphology of motoneurons (Fig. 8). The cell bodies were large and multipolar, and the appearance of an eccentric nucleus and Nissl substance was typical of these cells. The neuronal nature and the morphology of these cells were further investigated by staining the cultures with tetanus toxin followed by toxin antibody and fluorescent anti-antibody (Fig. 9). The number and extent of the processes is more clearly seen under these conditions than under phase contrast microscopy, where neurites may be obscured by nonliving material on the substrate.

Although the largest number of surviving neurons was seen on heat-treated substrates when cells were cultured in muscle-conditioned medium (Fig. 8), survival was less than $50 \%$, and true optimal conditions for the nurture of these cells have not been established.

\section{Discussion}

Several procedures have been reported for the isolation of subpopulations of cells from nerve tissues (Fischbach and Nelson, 1977; Berg and Fischbach, 1978; Masuko et
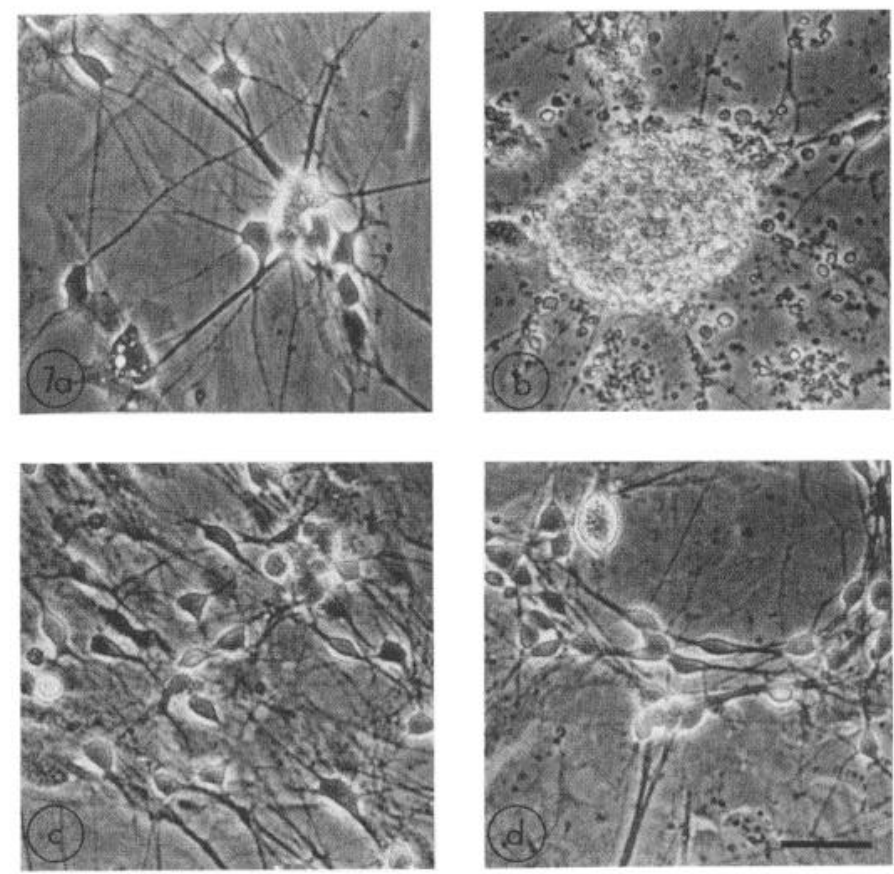

Figure 7. Morphology of fractionated rat spinal cord cells in culture. Cells were fractionated on discontinuous gradients as described in the text and placed in culture under standard conditions described under "Materials and Methods" (collagencoated dishes, Medium C supplemented with $10 \%$ FBS, $10 \%$ HS). The photomicrographs of the Fraction 1 cell culture (b) were prepared after 3 days in culture. After 4 days in culture, most of the Fraction 1 cells had lysed. The other cultures were photographed after 6 days in culture. $a$, Unfractionated cells; $b$, Fraction 1 cells; $c$, Fraction 2 cells; $d$, Fraction 3 cells. Magnification, $\times \quad 710 ;$ bar $=20 \mu \mathrm{m}$. 
al., 1979; Nagata and Tsukada, 1978; Poduslo et al., 1978). Bulk separations of neurons and glia dissociated from adult human, rat, and bovine brain have been accomplished using sucrose, sucrose/Ficoll, or sucrose/albumin density centrifugation (Nagata and Tsukada, 1978). While these procedures yield substantial separation of glia from neurons, the neuronal population remains very complex, and the cells are not amenable to long term culture in vitro. This approach has been used predominantly to study the biochemical composition and metabolism in the isolated cell fractions (Poduslo et al., 1978).

Treatment of dissociated cells from embryonic nerve tissue in cell culture with cytosine arabinoside or with fluorodeoxyuridine has been used to selectively deplete glial and mesenchymal cells from the culture (Fischbach and Nelson, 1977), since those cells withdraw from the mitotic cycle much later than the developing neurons. Other manipulations of the growth conditions, such as modifying the substrata, or using hormone-supplemented serum-free medium, can also selectively deplete non-neuronal cells from such cultures (Skaper et al., 1979; Yavin and Yavin, 1980). While these procedures are useful in obtaining stable, long term cultures of neurons, the resulting neurons are still functionally and morphologically diverse.

The present study describes a method for the enrichment of morphologically and functionally distinct subpopulations of neurons from dissociated embryonic spinal

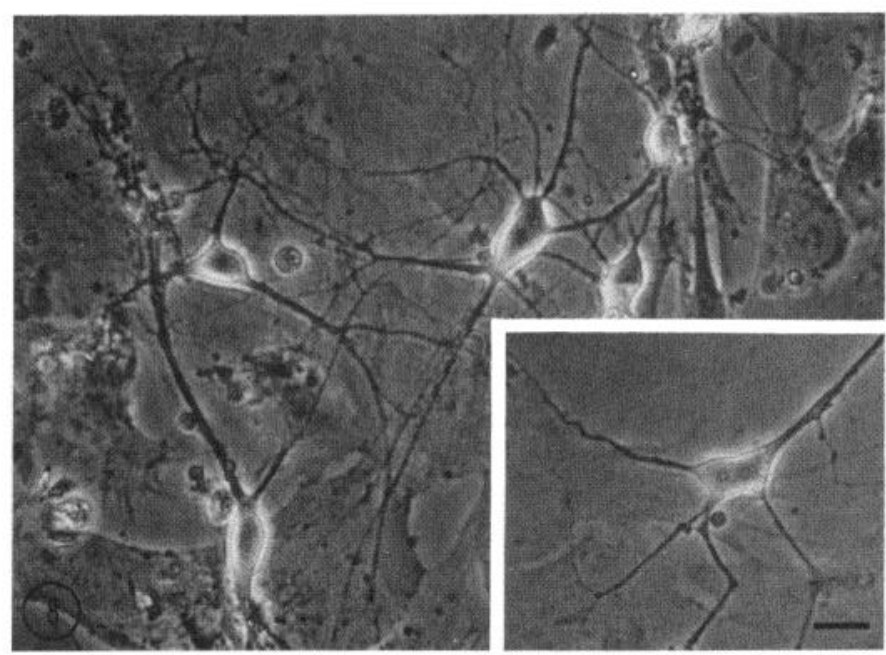

Figure 8. Culture of rat spinal cord Fraction 1 cells under optimum conditions. Substrata were prepared by culturing unfractionated rat spinal cord cells for 3 weeks under standard conditions. Heat treatment of the cell layers (Hawrot, 1980) was accomplished by replacing the medium with Medium A and incubating for $2 \mathrm{hr}$ at $55^{\circ} \mathrm{C}$. The resulting layers were washed with phosphate-buffered saline (twice) and stored for up to 3 weeks at $4^{\circ} \mathrm{C}$. Rat spinal cord Fraction 1 cells were prepared as described in the text and cultured on the heattreated substrata in muscle-conditioned Medium $\mathrm{C}$ supplemented with $10 \%$ HS (and 10\% FBS, first 4 days only). Insulin ( 80 units/liter) was added after 4 days. After 14 days in culture, unfixed cells were photographed using a Zeiss phase contrast microscope. Inset, Fraction 1 cell with evident eccentric nucleus and intracellular Nissl substance. Magnification, $\times \quad 890$; bar $=10 \mu \mathrm{m}$.

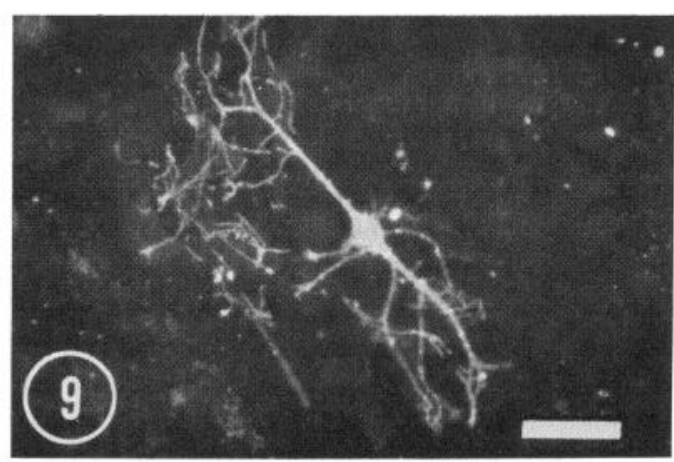

Figure 9. Indirect immunofluorescence of rat spinal cord Fraction 1 cells labeled with tetanus toxin. Fraction 1 cells were prepared and cultured as described in Figure 8, except paraformaldehyde-fixed cell substrates (Hawrot, 1980) were used. The substrate was prepared by culturing unfractionated rat spinal cord cells under standard conditions for 3 weeks. The resulting layer of cells was fixed by incubation with $4 \%$ paraformaldehyde in $0.12 \mathrm{~m}$ sodium phosphate $(\mathrm{pH} \mathrm{7.4)}$ for $45 \mathrm{~min}$ at $0^{\circ} \mathrm{C}$. Layers were polylysine-coated as described under "Materials and Methods." Cells were cultured for 4 days in $60 \%$ muscle-conditioned medium, 20\% Medium C, $10 \%$ FBS, and $10 \%$ HS, then for 12 additional days in the same medium without FBS. Cultures were labeled by incubation with $4 \mu \mathrm{g} /$ $\mathrm{ml}$ of tetanus toxin in Medium C (10\% FBS) for $30 \mathrm{~min}$ at room temperature, washed three times with the same medium (5 $\mathrm{min}$ (wash), incubated with goat anti-tetanus toxin antibody (1:20 goat antiserum in medium) for $30 \mathrm{~min}$ at room temperature, washed as above, incubated with fluorescein isothiocyanate-labeled rabbit anti-goat IgG (Cappel Laboratories 1:50) for $30 \mathrm{~min}$, and finally washed as above. Layers were fixed in $95 \%$ absolute alcohol, $5 \%$ glacial acetic acid at $-20^{\circ} \mathrm{C}$ for $15 \mathrm{~min}$, covered with glycerol, and photographed using a Zeiss fluorescence microscope. Fixed cell layers without Fraction 1 cells, treated in the same manner, did not fluoresce. Magnification, $\times \quad 490 ; b a r=20 \mu \mathrm{m}$.

cord. One cell fraction (Fraction 1) appears to be enriched for motoneurons. These cells provide an excellent system for the study of developmental influences on isolated neurons. Their distinct morphology includes a large cell body and multiple long processes. They are also distinct biochemically, since they contain the acetylcholine-synthesizing enzyme choline acetyltransferase (CAT). While this marker may not be completely specific for motoneurons, the purification of cells containing CAT activity surely results in a marked enrichment of motoneurons. During development, these cells have been shown to respond to signals provided by other cells, both in vivo (Chu-Wang and Oppenheim, 1978a, c) and in vitro (Giller et al., 1973, 1977). The isolation of motoneurons may help to distinguish and identify the various cellular and biochemical signals involved in the control of their development.

Several criteria for a useful enrichment procedure were defined at the outset of these studies. These included: (1) marked enrichment of CAT-containing cells, (2) high recovery, (3) high viability, (4) rapidity and ease of preparation under sterile conditions, and (5) reproducibility. Other procedures for the selection of motoneurons from embryonic chick spinal cord cells have been published 
(Berg and Fischbach, 1978; Masuko et al., 1979). Those procedures involved either the selection of nondividing cells from very early (60 to $66 \mathrm{hr}$ gestation) embryos (Masuko et al., 1979) or physical separation of leading and trailing fractions of cells sedimenting on a Ficoll gradient (Berg and Fischbach, 1978). While these procedures met some of the criteria outlined above, the number of cells recovered was generally small, and in addition, the separation of Ficoll gradients was a long process requiring special equipment.

Therefore, alternate procedures were explored, and density equilibrium centrifugation on iso-osmotic metrizamide density gradients was found to give markedly improved results based on the criteria outlined above.

Advantages of metrizamide density equilibrium fractionation. The use of metrizamide density gradients to purify cells from other tissue has been reported (MuntheKaas and Seglen, 1974; Seglen, 1976). There are several advantages of metrizamide over sucrose or sucrose/Ficoll mixtures. The most important is the ability to generate gradients in the appropriate density range without large osmolarity gradients. This eliminates the detrimental effects of sharp osmolarity shifts and the protracted dilution procedures necessary to retain cellular integrity (Nagata and Tsukada, 1978). In addition, metrizamide gradients have low viscosities, allowing rapid migration of cells to their equilibrium densities during centrifugation.

Differential migration of cells having different morphological and biochemical characteristics allowed the isolation of a fraction highly enriched in cholinergic cells having a distinct morphology and in vitro growth characteristics. The extension of this procedure to detect and purify other functional subpopulations of spinal cord cells may be accomplished using the same methods but using different functional markers. Experiments performed in this laboratory demonstrated that cells dissociated from other nerve tissues also showed distinct patterns on linear metrizamide gradients. Dissociated embryonic chick neural retina cells distributed in a multiphasic broad band over the same density range as spinal cord cells. Cholinergic cells from the neural retina banded as two distinct density populations which did not coincide with the profile of the other neural retina cells which banded at distinctly lower densities (R. Schnaar, unpublished data).

Two technical aspects of the procedure require careful consideration. Useful separations required that the cells remain dissociated during the fractionation procedure. This was accomplished by maintaining a low temperature and by avoiding the use of serum. Brief warming of the cells during the fractionation procedure led to rapid clumping (especially when rat spinal cord cells were used) and resulted in large reductions in recovery of Fraction 1 cells. Therefore, it is essential to keep the dissociated cells chilled on ice, and to prechill the gradients before cell application. Precision in preparing the density solutions was also found to be important to reproducibility. Therefore, all density solutions were adjusted to within $0.001 \mathrm{gm} / \mathrm{ml}$ using refractive index as an indication of density (see "Materials and Methods"). Using the above precautions, the procedure resulted in the rapid, simple, efficient, and reproducible fractionation of dissociated spinal cord cells. Several factors contribute to the convenience of the reported procedure. Metrizamide solutions of appropriate densities can be prepared in advance, sterilized by filtration, and stored for several weeks at $4^{\circ} \mathrm{C}$. Step gradients are easily prepared from these solutions, and the cells can be fractionated under sterile conditions without the use of special equipment. 'The entire fractionation procedure was routinely completed (from the application of the cell suspension to the resuspension of the isolated fractions) in less than $1 \mathrm{hr}$. The simplicity of the procedure is emphasized by the observation that sterility was easily maintained even though no antibiotics were used at any time.

Excellent reproducibility was also found. Among several experiments, recovery, viability, morphology, and biochemistry of the cells from the three isolated fractions remained relatively constant. The recovery of the cells from the gradients was high, averaging greater than $50 \%$. Average values from five chick spinal cord preparations (per embryo) were: $3.3 \times 10^{6}$ cells upon dissociation, 1.8 $\times 10^{6}$ cells recovered from the gradient, and $5.6 \times 10^{5}$ cells recovered in Fraction 1 . The recovery of the cholinergic-enriched cells (Fraction 1) per embryo is 5- to 15fold greater than that reported for other published procedures (Berg and Fischbach, 1978; Masuko et al., 1979) and represents an average recovery of $57 \%$ of the input choline acetyltransferase activity. This high recovery of the purified cells will facilitate further in vitro studies on the biochemistry of motoneuron development. The viability of the recovered cells, measured in the freshly recovered cells via trypan blue exclusion was high, ranging from 85 to $99 \%$. Additional confirmation of the viability of the isolated cells was obtained from measurement of the $\mathrm{LDH}$ activity. Lactate dehydrogenase is a soluble enzyme, and cell lysis results in its loss into the supernatant during the isolation procedures. Previous studies have used LDH measurement to assess viability of isolated cell preparations (Berg et al., 1972). Comparing the percentage of $\mathrm{LDH}$ activity recovered from the fractionation procedure $(49.7 \%)$ with the cell number $(53.5 \%)$, it is evident that greater than $92 \%$ of the $\mathrm{LDH}$ activity per cell is retained, a value which corresponds closely to that obtained for viability using the trypan blue method.

The described procedure results in a marked separation of cholinergic from non-cholinergic cells. Three- to 4-fold enrichment in CAT activity per cell in Fraction 1, was obtained, with nearly complete depletion of nonneuronal cells from that fraction. The cells in Fraction 3, in contrast, had almost no CAT activity. The CAT:LDH ratio of Fraction 1 cells averaged 72 -fold higher than that for Fraction 3 cells compared, for instance, with a 7 -fold difference between enriched and depleted fractions generated by the sedimentation fractionation method published by Berg and Fischbach (1978). The percentage of Fraction 1 cells which are motoneurons cannot be determined directly from these studies. However, in a recent study by Masuko et al. (1979), small numbers of highly purified motoneurons were isolated from very early chick embryus (60 hr gestation). The isolated motoneurons, after 7 days in culture, had 4 -fold to 5-fold higher CAT 
activity per cell than cells from unfractionated spinal cord of either $60-\mathrm{hr}$ or 4-day gestation embryos. This enrichment value agrees well with that of the current study. The CAT activity (adjusted for cell number) in co-cultures with chick muscle (for 6 days) was 5.1-fold higher in Fraction 1 cells than in unfractionated cells.

Suggestive evidence for purity can also be obtained by noting the distribution of morphological cell types. The larger cells in the unfractionated dissociated spinal cord preparation have distinctive characteristics when viewed with phase contrast optics, including nonrefractile cytoplasm, a distinct and large nucleus, and prominent nucleoli (Fig. 3). These cells become the predominant species in Fraction 1, comprising $86 \%$ of the cells (about a 4fold enrichment). These cells are depleted in Fraction 2 and are absent from Fraction 3. The distribution of this morphological cell type quantitatively parallels the distribution of CAT activity in various fractions. After cell culture under optimum conditions, nearly all of the surviving Fraction 1 cells are large multipolar neurons with long neurites (Fig. 6). Since CAT-active cells may copurify with other cells having a similar morphology, further experimentation is necessary to establish the purity of motoneurons in Fraction 1. Nevertheless, the above data suggest that the described procedure results in cholinergic cell enrichment as good or better than any published method, while providing much greater recovery.

The usefulness of the fractionation procedure is evidenced by the characteristics of the cholinergic-enriched cells in cell culture. All of the fractions contained neuronal cells, yet those in Fraction 1 were uniquely dependent on specific cell culture conditions for survival. This sensitivity may be due to selective toxicity of the procedure on the cholinergic cells. However, this is not a likely possibility since: (1) The cells recovered from the gradient are greater than $90 \%$ intact based on either trypan blue exclusion or lactate dehydrogenase retention. (2) Fraction 1 cells are isolated from that part of the gradient having the lowest metrizamide concentration. Neurons from Fractions 2 and 3, which were exposed to severalfold higher concentrations of the compound could be readily maintained in vitro under a variety of conditions. (3) Conditions could be found which allowed the cholinergic cells to be maintained in culture. Under optimal conditions, the cholinergic cells had a distinctive neuronal morphology, having large and highly refractile cell bodies and extremely long processes (Figs. 6, 8, and 9).

An alternate explanation of the selective sensitivity of the cholinergic-enriched neurons compared to other neurons is that the fractionation procedure removes another cell population necessary for motoneuron maintenance. Meyer et al. (1979) found that cells in spinal cord organotypic explants developed relatively high CAT activity in the absence of muscle and were insensitive to peripheral cell (muscle) input, while dissociated spinal cord cells were dependent on muscle cells to develop high CAT activity. They proposed that input to motoneurons from other spinal cord cells in close juxtaposition was essential to motoneuron maintenance and development. In this light, it should be noted that both Fraction 2 and Fraction 3 contain a considerable number of non-neuronal cells, while Fraction 1 is devoid of such cells.
In current studies, direct co-culture of the cholinergicenriched cells with muscle (Table III), culture on polylysine-coated dishes in the presence of muscle-conditioned medium (Table II, Fig. 6), or culture on treated layers of spinal cord cells with muscle-conditioned medium (Figs. 8 and 9) resulted in the maintenance (and development) of the isolated cholinergic cells. These data emphasize the possibility that some aspect provided by non-cholinergic cells is essential to their survival. The effects of the other cells may be 2-fold: (1) Non-neuronal cells flatten on the Petri dish, forming a layer to which neurons may attach (Figs. $5 a$ and $7 a$ ). Since attachment has been shown to be necessary for some cells to persist in culture, those cells may simply be providing an appropriate substratum. (2) Non-cholinergic cells may provide necessary signals for motoneuron survival. Embryological studies strongly suggest that peripheral tissue is necessary for motoneuron survival during normal development (White and Bennett, 1978).

The data outlined above suggest that both roles of non-neuronal cells may be expressed in this in vitro model system. The highly enriched motoneurons require both a highly adhesive substratum and a cellular "factor" which can be supplied by muscle. Fraction 1 cells from spinal cord can use highly adhesive polylysine-coated dishes or heat-treated cell layers as a substratum (Yavin and Yavin, 1974, 1980) and survive only when muscleconditioned medium is present (Table II and Figs. 6 and 8 ). Direct co-culture with muscle even causes an increase of choline acetyltransferase specific activity (Table III).

The ability of muscle or muscle-conditioned medium to induce choline acetyltransferase in parasympathetic (White and Bennett, 1978; Nishi and Berg, 1977, 1979) and sympathetic (Patterson and Chun, 1977) neurons has been reported previously. The relationship between the effect of muscle on motoneurons in this study and its effect on parasympathetic and sympathetic neurons has yet to be determined.

Other questions concerning the role of cells in the central nervous system and periphery on the maintenance of motoneurons, and their developmental expression of choline acetyltransferase activity, can be pursued more readily using purified cell fractions. Some of these include: (1) Which cell types can support the maintenance or development of the Fraction 1 cells? Are muscle cells essential, or will other cell types be able to serve this function? (2) Do non-neuronal cells from the spinal cord, or non-cholinergic neurons, support motoneuron maintenance and development? If so, are such effects additive or synergistic to effects supplied by muscle cells? (3) If specific cellular input is necessary for the motoneuron to persist in culture, what is the biochemical nature of the input? Are such effects based on cell-cell contacts, or are humoral factors involved? All of these questions may be more easily approached using purified cells. Succinct answers will require further assays for the effect of cellular input on the maintenance and development of the presumptive motoneurons in Fraction 1.

\section{References}

Adler, R., M. Manthorpe, and S. Varon (1979) Separation of neuronal and nonneuronal cells in monolayer cultures from chick embryo optic lobe. Dev. Biol. 69: 424-435. 
Berg, D. K. (1978) Acetylcholine synthesis by chick spinal cord neurons in dissociated cell culture. Dev. Biol. 66: 500-512.

Berg, D. K., and G. D. Fischbach (1978) Enrichment of spinal cord cell cultures with motoneurons. J. Cell Biol. 77: 83-98.

Berg, T., D. Bowman, and P. O. Seglen (1972) Induction of tryptophan oxygenase in primary rat liver cell suspensions by glucocorticoid hormone. Exp. Cell Res. 72: 571-574.

Bischoff, R., and H. Holtzer (1968) The effect of mitotic inhibitors on myogenesis in vitro. J. Cell Biol. 36: 111-127.

Cavanaugh, M. W. (1951) Quantitative effects of the peripheral innervation area on nerves and spinal ganglion cells. J. Comp. Neurol. 94: 181-219.

Christian, C. N., P. G. Nelson, J. Peacock, and M. Nirenberg (1977) Synapse formation between two clonal cell lines. Science 196: 995-998.

Chu-Wang, I., and R. W. Oppenheim (1978a) Cell death of motoneurons in the chick embryo spinal cord. I. A light and electron microscopic study of naturally occurring and induced cell loss during development. J. Comp. Neurol. 177: 33-57.

Chu-Wang, I., and R. W. Oppenheim (1978b) Cell death of motoneurons in the chick embryo spinal cord. II. A quantitative and qualitative analysis of degeneration in the ventral root, including evidence for axon outgrowth and limb innervation prior to cell death. J. Comp. Neurol. 177: 59-86.

Chu-Wang, I., and R. W. Oppenheim (1978c) Cell death of motoneurons in the chick embryo spinal cord. III. The differentiation of motoneurons prior to their induced degeneration following limb-bud removal. J. Comp. Neurol. 177: 87-112.

Fischbach, G. D., and P. G. Nelson (1977) Cell culture in neurobiology. In Handbook of Physiology. Vol. I.: The Nervous System, E. R. Kandel, ed., pp. 719-774, The American Physiological Society, Bethesda, MD.

Giller, E. L., B. K. Schrier, A. Shainberg, H. R. Fisk, and P. G. Nelson (1973) Choline acetyltransferase activity is increased in combined cultures of spinal cord and muscle cells from mice. Science 182: 588-589.

Giller, E. L., J. H. Neale, P. N. Bullock, B. K. Schrier, and P. G. Nelson (1977) Choline acetyltransferase activity of spinal cord cell cultures increased by co-culture with muscle and by muscle-conditioned medium. J. Cell Biol. 74: 16-29.

Hamburger, V., and H. L. Hamilton (1951) A series of normal stages in the development of the chick embryo. J. Morphol. 88: 49-92.

Hawrot, E. (1980) Cultured sympathetic neurons: Effects of cell-derived and synthetic substrata on survival and development. Dev. Biol. 74: 136-151.

Jacobson, M. (1978) Developmental Neurobiology, Plenum Press, New York.

Masuko, S., H. Kuromi, and Y. Shimada (1979) Isolation and culture of motoneurons from embryonic chicken spinal cords. Proc. Natl. Acad. Sci. U. S. A. 76: 3537-3541.

Meyer, T., W. Burkart, and H. Jockusch (1979) Choline acetyltransferase induction in cultured neurons: Dissociated spinal cord cells are dependent on muscle cells, organotypic explants are not. Neurosci. Lett. 11: 59-62.

Munthe-Kaas, A. C., and P. O. Seglen (1974) The use of metrizamide as a gradient medium for isopycnic separation of rat liver cells. FEBS Lett. 43: 252-253.

Nagata, Y., and Y. Tsukada (1978) Bulk separation of neuronal cell bodies and glial cells from mammalian brain and some of their biochemical properties. Rev. Neurosci. 3: 195-221.

Nelson, P. G., E. A. Neale, and R. L. MacDonald (1978) Formation and modification of synapses in central nervous system cell cultures. Fed. Proc. 37: 2010-2015.

Nishi, R., and D. K. Berg (1977) Dissociated ciliary ganglion neurons in vitro: Survival and synapse formation. Proc. Natl. Acad. Sci. U. S. A. 74: 5171-5175.

Nishi, R., and D. K. Berg (1979) Survival and development of ciliary ganglion neurons grown alone in cell culture. Nature 277: 232-234.

Patrick, J., S. Heinemann, and D. Schubert (1978) Biology of cultured nerve and muscle. Annu. Rev. Neurosci. 1: 417-443.

Patterson, P. H., and L. L. Y. Chun (1977) The induction of acetylcholine synthesis in primary cultures of dissociated rat sympathetic neurons. I. Effects of conditioned medium. Dev. Biol. 56: 263-280.

Poduslo, S. E., K. Miller, and G. M. McKhann (1978) Metabolic properties of maintained oligodendroglia purified from brain. J. Biol. Chem. 253: 1592-1597.

Ransom, B. R., E. Neale, M. Henkart, P. N. Bullock, and P. G. Nelson (1977) Mouse spinal cord in cell culture. I. Morphology and intrinsic neuronal electrophysiologic properties. J. Neurophysiol. 40: 1132-1150.

Schnaar, R. L., P. H. Weigel, M. S. Kuhlenschmidt, Y. C. Lee, and S. Roseman (1978) Adhesion of chicken hepatocytes to polyacrylamide gels derivatized with $N$-acetylglucosamine. J. Biol. Chem. 253: 7940-7951.

Schrier, B. K., S. H. Wilson, and M. Nirenberg (1974) Cultured cell systems and methods for neurobiology. Methods Enzymol. 32: 765-788.

Seglen, P. O. (1976) Preparation of isolated rat liver cells. Methods Cell Biol. 13: 29-83.

Skaper, S. D., R. Adler, and S. Varon (1979) A procedure for purifying neuron-like cells in cultures from central nervous tissue with a defined medium. Dev. Neurosci. 2: 233-237.

Varon, S. S., and R. P. Bunge (1978) Trophic mechanisms in the peripheral nervous system. Annu. Rev. Neurosci. 1: 327361.

Varon, S., and C. W. Raiborn (1969) Dissociation, fractionation, and culture of embryonic brain cells. Brain Res. 12: 180-199.

Weiss, P., M. V. Edds, and M. Cavanaugh (1945) The effects of terminal connections on the caliber of the nerve fibers. Anat. Rec. 92: 215-233.

White, W. B., and M. R. Bennett (1978) The survival and development of cholinergic neurons in the presence of striated muscle in vitro. Brain Res. 159: 379-384.

Yavin, E., and Z. Yavin (1974) Attachment and culture of dissociated cells from rat embryo cerebral hemispheres on polylysine-coated surface. J. Cell Biol. 62: 540-546.

Yavin, Z., and E. Yavin (1980) Survival and maturation of cerebral neurons on poly(L-lysine) surfaces in the absence of serum. Dev. Biol. 75: 454-459. 